\title{
MARKETING MANAGEMENT: AN INTERNATIONAL PERSPECTIVE
}


INTERNATIONAL MARKETING SERIES

Series Editor: Professor Christian Pinson, INSEAD 
MARKETING

MANAGEMENT: AN INTERNATIONAL PERSPECTIVE

Edited by

Kamran Kashani and Dominique Turpin

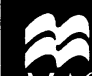

Business 
Selection and editorial matter

Copyright IMD - International Institute for Management Development, Lausanne, Switzerland 1999

Cases copyright before 1990:

Copyright 1999 by IMEDE, Lausanne, Switzerland. IMD - International Institute for Management Development, resulting from the merger between IMEDE, Lausanne and IMI, Geneva, acquires and retains all rights. Not to be used or reproduced without written permission directly from IMD.

Cases copyright after 1990:

Copyright 1999 by IMD - International Institute for Management Development, Lausanne, Switzerland. Not to be used or reproduced without written permission directlly from IMD.

Softcover reprint of the hardcover 1st edition 1999 978-0-333-75007-0

All rights reserved. No reproduction, copy or transmission of this publication may be made without written permission.

No paragraph of this publication may be reproduced, copied or transmitted save with written permission or in accordance with the provisions of the Copyright, Designs and Patents Act 1988, or under the terms of any licence permitting limited copying issued by the Copyright Licensing Agency, 90 Tottenham Court Road, London WIP OLP.

Any person who does any unauthorised act in relation to this publication may be liable to criminal prosecution and civil claims for damages.

The authors have asserted their right to be identified as the authors of this work in accordance with the Copyright, Designs and Patents Act 1988.

First published 1999 by

MACMILLAN PRESS LTD

Houndmills, Basingstoke, Hampshire RG21 6XS

and London

Companies and representatives throughout the world

ISBN 978-0-333-75008-7 ISBN 978-1-349-27529-8 (eBook)

DOI 10.1007/978-1-349-27529-8

A catalogue record for this book is available from the British Library.

This book is printed on paper suitable for recycling and made from fully managed and sustained forest sources.

$\begin{array}{llllllllll}10 & 9 & 8 & 7 & 6 & 5 & 4 & 3 & 2 & 1\end{array}$

$\begin{array}{llllllllll}08 & 07 & 06 & 05 & 04 & 03 & 02 & 01 & 00 & 99\end{array}$

Editing and origination by

Aardvark Editorial, Mendham, Suffolk 


\section{Contents}

List of Exhibits vii

Case Writers and Associates xiv

Preface $\quad x v$

Acknowledgements $\quad$ xvii

SECTION I INTRODUCTION TO MARKETING

Introduction to Marketing 3

The Job of the Marketing Manager 3

The Marketing Mission $\quad 3$

Putting It All Together 14

Cases in Section I $\quad 15$

$\begin{array}{ll}\text { Learning Points } & 15\end{array}$

Case 1.1 The Skisailer: Marketing a Young Investor's Dream 17

Case $1.2^{\mathrm{R}} \quad$ Delissa in Japan $\quad 35$

\section{SECTION II MARKETING DECISIONS: THE FIVE ‘PS’ 53}

Introduction: The Five 'Ps'

Segmentation and Positioning Decisions $\quad 55$

Product Management Decisions $\quad 56$

$\begin{array}{ll}\text { Pricing Decisions } & 60\end{array}$

Distribution Decisions $\quad 64$

$\begin{array}{ll}\text { Communication Decisions } & 68\end{array}$

$\begin{array}{ll}\text { Conclusions } & 73\end{array}$

$\begin{array}{ll}\text { Learning Points } & 73\end{array}$

Case 2.1 Konica Corp. $\quad 75$

Case 2.2 Kirin Brewery Co. Ltd (A) 104

Case 2.3 Daewoo Motor Company UK (A) 134

Case 2.3 Daewoo Motor Company UK (B) 147

$\begin{array}{lll}\text { Case } 2.4^{\mathrm{R}} & \text { Interdrinks } & 160\end{array}$

Case 2.5 Salomon: The Monocoque Ski 191

Case 2.6 Hong Kong \& Shenzhen Bank $(A) \quad 216$

Case 2.6 Hong Kong \& Shenzhen Bank (B) 222

Case 2.6 Hong Kong and Shenzhen Bank (C) 225 
Case 2.6 Hong Kong \& Shenzhen Bank (D) 241

Case 2.6 Hong Kong and Shenzhen Bank $(E) \quad 245$

Case 2.6 Hong Kong and Shenzhen Bank (F) 247

Case 2.7 Computron Inc., $1994 \quad 248$

Case 2.8 $8^{\mathrm{R}}$ Pharma Swede: Gastirup 256

Case 2.9 $9^{\mathrm{R}}$ Jordan A/S 280

Case 2.10 GPS One-hour Service (C): Moving Abroad 298

Case 2.11 Make Yourself Heard: Ericsson's Global Brand Campaign 326

Case 2.12 ${ }^{\mathrm{R}}$ Mediquip S.A. $\quad 345$

\section{SECTION III INTERNATIONAL MARKETING: GLOBAL INTEGRATION STRATEGY}

International Marketing: Global Integration and Strategy 357

Forces

359

P\&G Goes Global

Global Marketing: The Issues

Global Strategy: A Framework for Analysis

The Case of Integrated Solutions Inc.

Cases in Section III

Learning Points

Case 3.1 Libby's Beverages: Um Bongo Fruit Drink

\section{SECTION IV INTERNATIONAL MARKETING: STRATEGY IMPLEMENTATION}

International Marketing: Strategy Implementation 425

Chapter Coverage $\quad 426$

Structure $\quad 426$

$\begin{array}{ll}\text { Tasks } & 431\end{array}$

Process 433

Behavior $\quad 435$

Skills $\quad 437$

Cases in Strategy Implementation $\quad 439$

Learning Points $\quad 440$

Case 4.1 ${ }^{\mathrm{R}} \quad$ Alto Chemicals Europe $(A) \quad 441$

Case 4.1 ${ }^{\mathrm{R}} \quad$ Alto Chemicals Europe $(B) \quad 453$

Case 4.2 Sony Europa $(A) \quad 456$ 


\section{List of Exhibits}

\section{CASE 1.2}

Exhibit 1 Illustration of Skisailer from Product Brochure 30

Exhibit 2 Skisailer Market Potential 32

Exhibit $3 \quad$ Skisailer Achievable Sales Estimate 33

Exhibit 4 World Market of Alpine and Cross-country Skis 34

\section{CASE 2.1}

Exhibit $1 \quad$ Konishiroku Photo Industry (Konica) Selected Data 84

Exhibit 2 World Amateur Photographic Exposures (units in bns) 86

$\begin{array}{lll}\text { Exhibit } 3 & \text { Japanese Photography Exposures (bn shots) } & 87\end{array}$

Exhibit 4 Japanese Amateur Total Photographic Expenditures ( $¥ 100 \mathrm{mn}) \quad 88$

Exhibit 5 The World Photofinishing Industry (US\$100 mn) 89

Exhibit 6 Photofinishing Sales in Japan ( $¥$ bn) 90

Exhibit $7 \quad$ Sales of Data Processing by Type of Outlet (\% of total value) 91

Exhibit $8 \quad$ Photofinishing Prices in Japan (¥) 92

Exhibit 9 Sales of Still Cameras in Japan (¥mn) 93

Exhibit 10 Sales of Cameras in Japan by Sex and Age Group (\%) 94

Exhibit 11 Sales of Photographic Film in Japan by Sex and Age Group 95

Exhibit 12 Market Shares in the 35mm SLR Camera Industry in Japan (1975-86) 96

Exhibit 13 Sales of Color Negative Film in Japan by Size, Sensitivity and

Prints (Film for Amateurs Only)

Exhibit 14 Konishiroku Photo Industry Product Line for Color Print Film

(Film for Amateurs Only)

Exhibit 15 Konishiroku Photo Industry Product Line for Color Print Film

(Film for Amateurs Only)

Exhibit 16

Comparative Retail Prices for Color Print Film in Japan 1987*

100

Exhibit 17 Photographic Subjects for Color Prints by Sex and Age Group

Exhibit 18 Photographic Subjects for Color Prints by Season*

(ISO100, Color Prints 1980-86)**

Exhibit 19 Fuji Photo Film Selected Data 


\section{CASE 2.2}

$\begin{array}{lll}\text { Exhibit } 1 & \text { The World Beer Industry (1987) } & 118\end{array}$

Exhibit 2 Selected Financial Data 119

Exhibit 3 Comparative Market Shares in the Japanese Beer Industry $\left(1949-87^{*}\right) 120$

Exhibit 4 Segmentation of the Beer Market in Japan by Product

Categories and Brewers in 1987 ( $\times 10,000$ kiloliters)

Exhibit 5 Comparative Marketing Expenditures of the Major Japanese

Brewers 1983-87 (¥ bn) 122

Comparative Advertising Expenditures per Media, 1987 (in \%) 123

Exhibit $6 \quad$ Sapporo Breweries' Selected Financial Data 124

Exhibit 7 Asahi Breweries' Selected Financial Data 125

$\begin{array}{lll}\text { Exhibit } 8 & \text { Positioning Map for Beer Products } & 126\end{array}$

$\begin{array}{lll}\text { Exhibit } 9 & \text { Asahi's Super Dry Label } & 127\end{array}$

$\begin{array}{lll}\text { Exhibit } 10 & \text { Kirin's Lager Beer Label } & 128\end{array}$

Consumer Opinions on Dry Beer in Japan $\quad 129$

\section{CASE 2.3A}

Exhibit 1 New Car Market Shares and Distribution Structure by

Manufacturer: 1992-94 140

Exhibit 2A Overview of Segmentation of the UK Car Market 141

Exhibit 2B Market Share by Model: Lower- and Upper-medium Segments (1993) 142

Exhibit 2C Private Buyers - Main Reasons for Purchase 143

Exhibit 2D Price Ranges of Competing Models: August 1994

$\begin{array}{ll}\text { Exhibit } 3 \quad \text { Largest UK Franchised Dealer Groups } & 145\end{array}$

Exhibit 4 Brand and Retail Advertising for Top Car Manufacturers 146

\section{CASE 2.3B}

Exhibit 1 Daewoo Launch Advertising 152

Exhibit 2 New Car Registrations in UK by Marque: 1994-97 157

Exhibit 3 Daewoo New Model Pricing 159

\section{CASE 2.4}

$\begin{array}{lll}\text { Exhibit } 1 & \text { Switzerland and IDC's Geographic Coverage* } & 173\end{array}$

$\begin{array}{lll}\text { Exhibit } 2 & \text { Partial Organization Chart } & 174\end{array}$

$\begin{array}{lll}\text { Exhibit } 3 \quad \text { Income Statement (in thousand Sfrs) } & 175\end{array}$

$\begin{array}{lll}\text { Exhibit } 4 & \text { Balance Sheet (in thousand Sfrs) } & 176\end{array}$ 
$\begin{array}{lll}\text { Exhibit } 5 & 177\end{array}$

Exhibit $6 \quad 1997$ Sales by Outlet (in thousand Sfrs) 178

Exhibit 71997 Sales by Outlet (in thousands of bottles) 179

Exhibit $8 \quad$ Average Ex-factory Prices by Outlet ${ }^{*}$ in 1997 (Sfrs) 180

$\begin{array}{lll}\text { Exhibit } 9 & \text { Variable Manufacturing Costs* (in Sfrs) } & 181\end{array}$

Exhibit 10 Advertising and Promotion Expenditures (in thousand Sfrs) 182

Exhibit 11 Swiss Soft Drink and Mineral Water Consumption (millions of liters) 183

Exhibit 12 National Market Shares of Top Bottling Companies (1997, liters) 184

$\begin{array}{lll}\text { Exhibit } 13 & \text { Representative Consumer Prices (in Sfrs) } & 185\end{array}$

Exhibit 14 Share of Food Chains in Total Consumer Purchases (\%) 186

Exhibit 15 Estimated Sales of Competitors Within IDC's Region 187

Exhibit 16 Breakdown of Selling Expenses (Sfrs 000s) 188

$\begin{array}{llr}\text { Exhibit } 17 & \text { Age and Service Profile of Salesmen } & 189\end{array}$

Exhibit 18 Performance Evaluation Form 190

\section{CASE 2.5}

Exhibit 1 Salomon S.A., Sales and Profits (FF mn) 205

Exhibit 2 Growth of Sales and R\&D Expenditures Index $(1983-84=100) \quad 206$

Exhibit $3 \quad$ Salomon S.A., Five-Year Financial Summary 207

Exhibit 4 Ski Sales in the 1980s (millions of pairs) 209

Exhibit $5 \quad$ 1986-87 Sales by Country (thousands of pairs) 210

Exhibit 6 The Market Price Structure in the Ski Market 211

Exhibit $7 \quad$ Sales by Manufacturers (thousands of pairs) 212

$\begin{array}{lll}\text { Exhibit } 8 & \text { Types of Ski Structure } & 213\end{array}$

$\begin{array}{lll}\text { Exhibit } 9 & \text { The Ski Purchasing Process } & 214\end{array}$

$\begin{array}{lll}\text { Exhibit } 10 & \text { The Ski Concept: Progressive Profile } & 215\end{array}$

\section{CASE 2.6A}

Exhibit 1 Organization Chart of the Hong Kong \& Shenzhen Bank

\section{CASE 2.6C}

Exhibit $1 \quad$ Step 1a: Summary of Clients' Expectations 226

Exhibit 2A Step 1a: Division's Performance 228

Exhibit 2B Step 1a: Division's Performance $\quad 229$

Exhibit 2C Step 1a: Division's Performance $\quad 230$

Exhibit 2D Step 1a: Division's Performance 231 
CASE 2.6C

Exhibit 3A Step 1b: Sensitiveness of the Employees Towards Quality

Exhibit 3B Step 1b: Sensitiveness of the Employees Towards Quality

Exhibit 3C

Step 1b: Sensitiveness of the Employees Towards Quality

Exhibit 3D

Step 1b: Sensitiveness of the Employees Towards Quality

Exhibit 3E

Step 1b: Sensitiveness of the Employees Towards Quality

Exhibit 3F

Step 1b: Sensitiveness of the Employees Towards Quality

237

Exhibit 3G

Step 1b: Sensitiveness of the Employees Towards Quality

238

Exhibit 3H

Step 1b: Sensitiveness of the Employees Towards Quality

239

Exhibit 3l

Step 1b: Sensitiveness of the Employees Towards Quality

\section{CASE 2.6D}

Exhibit 1 Examples of Company Charters 243

Exhibit 2 The Hong Kong \& Shenzhen Bank's Quality Chart

\section{CASE 2.7}

Exhibit 1 Estimated Price for the 1000X Computer for the Slavisky Experimental Pilot Plant based on 'Usual' Calculations

Exhibit 2 1993 Market Share for Companies Selling Medium-priced

Computers to the Polish Market (US\$)

\section{CAse 2.8}

Exhibit 1 Pharma Swede (Sales in \$ mn) 270

Exhibit 2 Partial Organization Chart 271

Exhibit $3 \quad$ The Development of a New Drug 272

Exhibit 4 Product Pricing and Government Relations 273

Exhibit $5 \quad$ The Oral Osmotic Delivery System (OROS) 274

Exhibit 6 Sales and Market Shares in Major European Markets*

(Sales in \$ mn) 275

Exhibit $7 \quad$ Retail Prices in Europe (Daily Treatment Cost) 276

Exhibit 8 Price Setting and Reimbursement in the EU 277

$\begin{array}{lll}\text { Exhibit } 9 & \text { Relative Retail Prices of Gastirup } & 279\end{array}$

\section{CASE 2.9}

Exhibit 1 Selected Financial Results (millions of Norwegian kroner) 
Exhibit 3 The World Market for Toothbrushes (data unavailable for some countries)

Exhibit 4 Jordan Market Share by Country

Exhibit 5 Major Competitors in Toothbrushes: Selected Financial and Operating Statistics ( $\$ \mathrm{mn}$ )

Exhibit $6 \quad$ Major Competing Brands of Toothbrushes

Exhibit 7 British Toothbrush Market

\section{CASE 2.10}

Exhibit 1A Representation of the GPS Group 310

Exhibit 1B GPS Consolidated Profit \& Loss 1992-96 311

Exhibit 2 The Spirit of GPS 312

Exhibit $3 \quad$ Photos of GPS Stores 313

Exhibit $4 \quad$ Quick Look at the Optical Industry 315

Exhibit 5 Costs and Income of a Typical Grand Optical or La Générale d'Optique Store in France 318

Exhibit $6 \quad$ Grand Optical Facts and Figures as per December $1996 \quad 319$

Exhibit $7 \quad$ Overview of International Competitors 320

Exhibit 8 Positioning of the International Optical Chains 322

Exhibit 9 Quantitative Market Data 323

Exhibit 10 Competitors' Profiles per Market (as evaluated by the IMD MBA project team)

\section{CASE 2.11}

Exhibit 1 Partial Organization Chart: Ericsson Group and Mobile Phones and Terminals

Exhibit 2 Mobile Phones: Global Market Shares 337

Exhibit $3 \quad$ Pan-European Press Advertising $1995 \quad 338$

Exhibit 4 James Bond Tie-in Advertising: Austria 1997

Exhibit $5 \quad$ Global Brand Campaign Billboard Advertising 1998

Exhibit $6 \quad$ Global Brand Campaign TV Commercial Storyboards 1998

Exhibit $7 \quad$ European Region's Product Campaign Press Advertising $1998 \quad 342$

Exhibit $8 \quad$ Local Product Campaign Press Advertising 1997

Exhibit $9 \quad$ Radio Systems Press Advertising 1998

\section{CASE 2.12}


CASE 3.1

Exhibit $1 \quad$ Nestlé's 1988 Sales Breakdown 386

Exhibit $2 \quad$ Partial Corporate Nestlé Organization Chart 387

Exhibit $3 \quad$ Segmentation of the US Beverage Market, 1988

Exhibit 4 US Competitive Overview: Who is Who in Shelf-stable Juice 389

Exhibit 51988 Dollar Volume and Share Trends: Total US Juice/Drinks Category (US\$ thousands) 391

Exhibit 6 Libby's US Division Reporting Structure 392

Exhibit 7 Juicy Juice: Sample Labels 393

Exhibit 8 Juicy Juice Positioning (Based on 1987 Creative) 394

Exhibit 9 Juicy Juice Storyboard 395

Exhibit 10 Hawaiian Punch Storyboard 396

Exhibit 11 Juicy Juice Consumer Profile 397

Exhibit 12 Highlights of 1989 Marketing Plan Juicy Juice 398

Exhibit 13 Segmentation of the UK Beverage Market, 1988 (US\$ mn) 399

Exhibit 14 Um Bongo Brik Paks 400

Exhibit 15 Um Bongo Commercial Storyboard 401

Exhibit 16 UK Consumer Data on Um Bongo* 402

Exhibit 17 Spanish Fruit Juice and Drinks Market* 1988

Exhibit $18 \quad$ Portuguese Fruit Juice and Drinks Market ${ }^{*} 1988$

Exhibit 19 US Um Bongo Research: Interpretative Summary and

Selected Findings

405

\section{CASE 3.2}

Exhibit 1 The Hilti Product Line $\quad 416$

$\begin{array}{lll}\text { Exhibit } 2 & \text { Global Strategy } & 417\end{array}$

\section{CASE 3.3}

Exhibit 1 Haaks International Partial Organization Chart

\section{CASE 4.1A}

Exhibit 1 Stabilizer Market Segments (1989) 450

Exhibit 2 Stabilizer Marketing Organization 451

Exhibit $3 \quad$ Partial Job Definitions 452 


\section{CASE 4.1C}

Exhibit $1 \quad$ Sony Product Innovations $\quad 475$

Exhibit 2 History of Sony's Operations in Europe 476

Exhibit 3 Relations Between European Country Management and Sony Tokyo 477

Exhibit 4 European Consumer Electronics Market Size and Shares of Major Producers $\quad 478$

Exhibit 5 European Consumer Electronics Sales Trends by Product Category 479

Exhibit 6 European Consumer Electronics Sales Trends by Country and Region 480

Exhibit $7 \quad$ Per Capita Expenditure on Consumer Electronics (1992) 481

Exhibit $8 \quad$ Shares of Consumer Electronics by Channel 482

Exhibit 9 Partial Organization Chart: European Sales and Marketing Operations 483

Exhibit 10 The Butterfly Concept $\quad 484$

Exhibit 11 SymphONY Europa 485

Exhibit 12 Shin Takagi's Career History at Sony 486

$\begin{array}{lll}\text { Appendix } & \text { Partial Text of Organization Announcement } & 487\end{array}$ 


\section{Case Writers and Associates}

Case 1.1 Dominique Turpin and Kamran Kashani

Case $1.2^{\mathrm{R}}$ Juliet Burdet-Taylor and Dominique Turpin

Case 2.1 Dominique Turpin

Case 2.2 Dominique Turpin with Joyce Millar

Case 2.3 Debra Riley, under the supervision of Sean Meehan

Case 2.4 Srinivasa Rangan and Janet Shaner under the supervision of Kamran Kashani

Case 2.5 Francis Bidault

Case 2.6 Dominique Turpin and Giana Klaas

Case 2.7 Ralph Z. Sorenson, revised by Dominique Turpin

Case 2.8 Kamran Kashani with Robert C. Howard and Janet Shaner

Case 2.9 ${ }^{\mathrm{R}}$ David $\mathrm{H}$. Hover and Janet Shaner under the supervision of Per V. Jenster and Kamran Kashani

Case 2.10 Els van Weering under the supervision of Jacques Horovitz

Case 2.11 Kamran Kashani

Case 2.12 $\quad$ Kamran Kashani

Case 3.1 Kamran Kashani with Robert C. Howard

Case 3.2 Peter Killing

Case 3.3 ${ }^{\mathrm{R}} \quad$ Kamran Kashani with Janet Shaner

Case 4.1 ${ }^{R} \quad$ Kamran Kashani

Case 4.2 Kamran Kashani and J.B.M. Kassarjian 


\section{Preface}

This book intends to respond to a growing interest in the internationalization of business and the challenges of conducting marketing in markets other than one's own. In a shrinking world of business, thanks to ease of transportation, instant communications, rapid deregulation of financial markets and trade, this book introduces the students of international marketing and management to the excitement, challenges and opportunities of global markets and offers a practical means of learning about international marketing issues.

This book is primarily designed for international marketing teaching purposes but it can also serve to cover more general management issues in international business such as crosscultural management, strategic alliances and partnerships. The cases are based on our personal observations of companies and their operations in countries where the IMD faculty has done consulting or research. We have used every case presented in this book successfully with both IMD MBA participants and executives. Taken together, they cover subjects in different international marketing contexts: evaluating the potential of different markets around the globe, launching or re-launching a product or service in a global context, managing the marketing mix in an international or new environment, implementing a global marketing strategy, dealing with crosscultural marketing issues, managing alliances and partnership strategies in international marketing.

The cases in this book are not intended to be examples of 'best practices' or, for that matter, of ineffective management. We selected them for their general interest and pedagogical value, the overall picture of doing business overseas they paint, and the specific issues on international marketing they present. All the cases in this book are comprehensive and are based on real business situations. They include selected information about the companies, the events and circumstances they operate in. All cases are especially designed for teaching - they highlight the issues important in developing a management framework by engaging participants in probing discussions. Most importantly, this book features real management issues. The views of the managers and the experiences of the companies, different as they are from each other and from those of academic scholars, are invaluable because they are based on the field experiences of real world marketers.

The structure of the book has the following flow of topics: it begins with an overview and an examination of marketing fundamentals before progressing to the more advanced issues 
in global marketing. The four parts of the book are organized as follows:

Section I: Introduction to Marketing provides a general picture of international marketing issues, market analysis and decisions. It introduces the students to the complexity of the international environment and provides a general overview of key managerial issues in international marketing such as evaluating the size of a new market for an innovative product or seizing the opportunities for growth in different markets.

Section II: Marketing Decisions introduces the students to the key decision areas in marketing, the so-called ' 5 Ps': segmentation and positioning; product and service policy; pricing; distribution; and communication.

Section III: International Marketing Integration \& Planning focuses on issues coming out of companies trying to adapt their international marketing towards a coherent integrated strategy. The introductory chapter highlights some of the pertinent issues here, such as local versus global bias in marketing decision-making, and sets the stage for the cases that follow.

Section IV: International Marketing Organization of Strategy Implementation examines important issues left out of most international marketing case books: not only the organizational structure (which is usually covered) but also elements of strategy implementation. This latter set of issues deals with how a management team undertakes actions necessary to implement a given strategy. Implementation issues are especially critical when a given strategy cuts across many organizational, cultural and market divisions - as is often the case in international marketing.

An Instructor's Manual is available for adopters of this book.

KAMRAN KaSHANI AND DOMINIQUE TURPIN 


\section{Acknowledgements}

We would like to thank our colleagues at IMD for their generous support of our effort to produce this book. Many people have contributed to the realization of our project, but special mention should be made of Persita Egeli-Farmanfarma, IMD Case Administrator, Gordon Adler, IMD Senior Writer, and his assistant Cheryl Petroski, and our proofreader, Michelle Perrinjaquet, for providing us with the assistance necessary to put this book together. We are equally grateful to Janet Shaner, Research Associate, who worked on updating many of the cases that appear in this book. Her work has resulted in exciting new and timely teaching material. Our thanks also go to several of our current and former colleagues for contributing their fine cases to this collection. They are Professors Francis Bidault, Jacques Horovitz, Per Jenster, J.B.M Kassarjian, Peter Killing, Christopher Lovelock, Sean Meehan and Ralph Z. Sorenson. We are also grateful to the research staff who assisted them in developing these cases.

As always, we owe special thanks to our families for their understanding and unwavering support during the completion of this project.

Every effort has been made to trace all the copyright holders but if any have been inadvertently overlooked the publishers will be pleased to make the necessary arrangements at the first opportunity. 